Environment Conservation Journal 14(1\&2) 93-96, 2013

ISSN 0972-3099 (Print) 2278-5124 (Online)

Abstracted and Indexed

\title{
Effect of tannery effluent on germination, seedling growth and pigment content of Triticum aestivum L. var. PBW-373
}

\author{
Richa Kohli and Piyush Malaviya $\bowtie$
}

Received: 15.09.2012

Accepted: 8.01.2013

\begin{abstract}
The present study has been focussed on the effect of untreated tannery effluent on germination, seedling growth and pigment contents of wheat (Triticum aestivum L. var. PBW-373).Germination studies were conducted with wheat seeds having various concentrations of $(4.5,9,13.5$, and $18 \%)$ tannery effluent and five treatments $\left(E_{0}, E_{4.5}, E_{9}, E_{13.5}\right.$ and $\left.E_{18}\right)$.The +ve germination parameters i.e. cumulative percent germination, germination index etc. found to be maximum in $E_{4.5}$. The -ve germination parameters like delay index, percent inhibition showed minimum values for $E_{4.5}$. Growth parameters also decreased with increase in effluent concentration. The pigment contents i.e. chlorophyll-a and chlorophyll-b also showed good results at $\mathrm{E}_{4.5}$.
\end{abstract}

Keywords :Chromium, Pigments, Pollution, Germination,Tannery effluent,Triticum aestivum

\section{Introduction}

Industries are the valuable assets of a country and are undoubtedly aboon to mankind as they fulfill most of the man's needs by manufacturing a wide variety of products as well as eradicate poverty by generating employment sources but serious environment degradation is also caused by their toxic discharges (Malaviya and Sharma, 2011). The effluents discharged into land and water spoil surface and ground water quality, soil, vegetation and productivity of crop grown which deteriorates human health (Khurana and Pritpal, 2012). Tannery effluents are ranked as one of the highest polluted effluents among all others industrial discharge. In India, tanneries are mostly located in Tamil Nadu, West Bengal, Maharashtra, Punjab, Karnataka, Andhra Pradesh and Kanpur (U.P). The Tannery effluent is characterized by high toxicity due to chromium, higher dissolved solids, and high salinity. To assess pollutants toxicity, plants are the best ecological monitors (Nath et al., 2009).

Although various workers have suggested suitable application rates for tannery effluent under different

Author's Address

Department of Environmental Science, University of Jammu, Jammu, India

E-mail:piyushmalaviya@rediffmail.com

Copyright by ASEA

All rights of reproduction in any form reserved conditions (Karunyal et al., 1994; Thangavel and Balagurunathan, 2002), the local studies are essential to determine optimum loading rates in order to avoid the possible reduction in crop yields because of inorganic toxicity. In the present study, an attempt has been made to study the effect of different concentrations of tannery effluent on germination, seedling growth and pigment content of wheat (Triticum aestivum L. var. PBW-373).

\section{Material and Methods}

The effluent was collected from a tannery industry in CLRI, Leather complex, Kapurthala Road, Jalandhar in plastic containers and kept under refrigeration. The effluent was analyzed for various physico-chemical parameters by standard methods according to Greenberg et.al. (1995). Certified seeds of wheat variety PBW-373 were procured from the Directorate of Agriculture, Talab Tillo, Jammu (J\&K). Wheat seeds were surface sterilized with carbendazim for two minutes and washed with distilled water to remove surface contamination. Twenty seeds were arranged at equal distance in petriplates of diameter $14 \mathrm{~cm}$ lined with two filter papers. Different concentrations of the tannery 
effluent viz. $4.5 \%, 9 \%, 13.5 \%$ and $18 \%$ were made by adding distilled water and sprinkled into respective petriplates designated as $E_{4.5}, E_{9}, E_{13.5}$ and $E_{18}$. The petriplate poured with tap water was used as control $E_{0}$. Similarly three replicates of each set were maintained and kept in a BOD incubator at room temperature of $28 \pm 2^{\circ} \mathrm{C}$. Filter papers were moistened regularly during experiment to prevent dryness of the seeds. The number of seeds germinated on each day was noted until it became constant. The seeds were considered to have germinated when the radical pierced through the seed-coat. On $10^{\text {th }}$ day seedlings were removed and germination parameters viz. cumulative percent germination, germination index, delay index, germination value, peak value, speed of germination, germination period, percent inhibition andvigour index were estimated (Czabator, 1962). Growth parameters like root length, shoot length, root-shoot ratio, total seedling length, fresh weight of root, dry weight of root, fresh weight of shoot, dry weight of plant, biomass (fresh and dry weight of plant), moisture content were also estimated (Greenberg etal., 1995). For estimation of pigment content the leaves were extracted in $80 \%$ acetone and the absorbance of pigment extract was measured spectrophotometrically at wavelength 663 and $645 \mathrm{~nm}$ for chlorophyll content (Arnon, 1949) and 480 and $510 \mathrm{~nm}$ for carotenoid content (Duxbury and Yentsch, 1956).

\section{Results and Discussion}

The tannery effluent used for the present study was dark bluish green incolour withan unpleasant odour.The physicochemical characteristics of the $100 \%$ effluent exhibited low pH (3.61), EC (67.5 $\mathrm{mS} / \mathrm{cm}$ ) and turbidity (023 NTU). The average values of total suspended solids (1580 mg/l), sodium (4210 mg/l), chloride (4570mg/l) and COD $(1840 \mathrm{mg} / \mathrm{l})$ were also estimated.The effect of tannery effluent on various germination parameters of Triticum aestivum L. var. PBW-373 are shown in Table 1. It was observed that the average values for +ve germination indices were highest [cumulative percent germination (78.33), germination index (120.116), germination value (1539.583), peak value (19.583), speed of germination (7.833), and vigour index (2214.266)] in $\mathrm{E}_{4.5}$ (4.5\% effluent concentration) and lowest in effluent treatment $\mathrm{E}_{18}$
(18\% effluent concentration).The average value for -ve germination parameters like delay index was negative in $\mathrm{E}_{4.5}$ and zero in other treatments. The value of percent inhibition was lowest (-1.666) in $\mathrm{E}_{4.5}$ and increased with increasing effluent concentration. The value of germination period (days) was found to be two days in all the effluent treatments. From the study it is evident that at $4.5 \%$ effluent concentration, the values of all the +ve germination parameters were maximum. It may be due to the reason that up to $4.5 \%$ concentration, the seedlings are getting some nutrients which promote seed germination and beyond that it becomes toxic. More or less similar results have been observed by Sharma et al. (2002) while studying the effect of distillery effluent on sugar beet. Sahai and Srivastava (1986) also observed that lower concentration distillery wastewater (2.5\%) promoted seed germination of Cajanus cajan. High osmotic pressure caused due to high salt concentration in the effluent might be responsible for reduced seed germination.

Table 2 reveals the effect oftannery effluent on growth parameters of Triticum aestivum PBW-373 seedlings. The average values of root-shoot ratio (in terms of length) of seedlings showed an increase at $E_{4.5}$, followed by $E_{0}$ and the values were minimum in $\mathrm{E}_{18}$ treated seedlings. The reduction in root length, shoot length and root-shoot ratio might be due to high salinity of tannery effluent (Rao and Kumar, 1983). The root system is adversely affected by the higher concentration of effluent which results in reduction of root-shoot ratio (Vijayarengan, 2003). Also heavy metals accumulation in roots causes decrease in root growth. The biomass also showed an increase at $\mathrm{E}_{4.5}$ tannery effluent concentration. The values of \% moisture of $\mathrm{E}_{0}$ and $\mathrm{E}_{4.5}$ also showed similar pattern and increase in effluent concentration caused decrease in \% moisture. Table 3 reveals the effect of different concentrations of tannery effluents on pigment content of Triticum aestivum seedlings. The chlorophyll a, chlorophyll b and total chlorophyll have been increased up to $\mathrm{E}_{4.5}$ effluent concentration, followed by control and then gradually decreased with an increase in effluent concentration. It may be due to chromium compounds present in the effluent which caused 
Table 1: Effect of different concentrations of tannery effluent on germination parameters ${ }^{1}$ of Triticum aestivum L.var. PBW-373 on $10^{\text {th }}$ day of germination

\begin{tabular}{|c|c|c|c|c|c|c|c|c|c|}
\hline 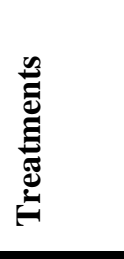 & 胥 & 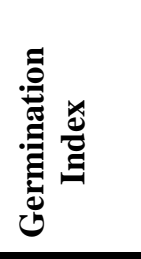 & 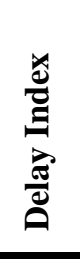 & 总兽 & 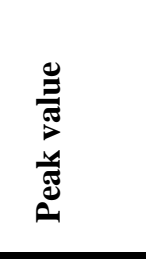 & के & 氞兽总 & 递 & 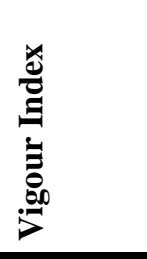 \\
\hline $\begin{array}{l}\text { Control } \\
\left(E_{0}\right)^{2}\end{array}$ & 76.66 & - & 0 & 1475 & 19.166 & 7.666 & 2 & - & 2004.933 \\
\hline $\mathrm{E}_{4.5}$ & 78.33 & 120.116 & -.11 & 1539.583 & 19.583 & 7.833 & 2 & -1.666 & 2214.266 \\
\hline $\mathrm{E}_{9}$ & 73.33 & 91.15 & 0 & 1345.833 & 18.333 & 7.333 & 2 & 3.333 & 1848.283 \\
\hline $\mathrm{E}_{13.5}$ & 71.66 & 69.933 & 0 & 1289.583 & 17.916 & 7.166 & 2 & 5.000 & 1540.416 \\
\hline $\mathrm{E}_{18}$ & 70.00 & 66.396 & 0 & 1229.166 & 17.500 & 7.000 & 2 & 6.666 & 1468.500 \\
\hline
\end{tabular}

${ }^{1}$ Mean of three replicates, ${ }^{2} \mathrm{E}_{0}$ : tap water, $\mathrm{E}_{4.5}, \mathrm{E}_{9}, \mathrm{E}_{13.5}, \mathrm{E}_{18}: 4.5,9,13.5$ and $18 \%$ of tannery effluent, respectively.

Table 2: Effect of different concentrations of tannery effluent on growth parameters ${ }^{1}$ of Triticum $^{\text {int }}$ aestivum L.var. PBW-373 seedlings on $10^{\text {th }}$ day of germination

\begin{tabular}{|c|c|c|c|c|c|c|c|}
\hline 芫 & 预 & 롱 & 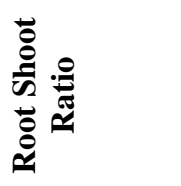 & 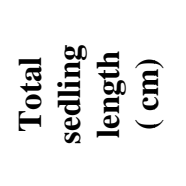 & 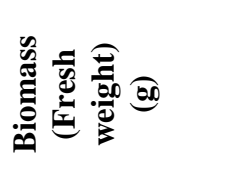 & 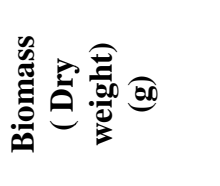 & 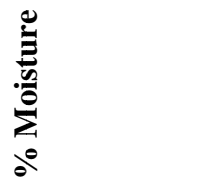 \\
\hline $\begin{array}{l}\text { Control } \\
\left(\mathrm{E}_{0}\right)^{2}\end{array}$ & $10.66 \pm 0.362$ & $15.523 \pm 0.501$ & $0.68 \pm 0.001$ & $26.18 \pm 0.86$ & $0.1288 \pm 0.0009$ & $0.0276 \pm 0.0027$ & $78.509 \pm 2.269$ \\
\hline $\mathrm{E}_{4.5}$ & $12.51 \pm 0.297$ & $15.75 \pm 0.808$ & $0.79 \pm 0.01$ & $28.27 \pm 0.37$ & $0.1313 \pm 0.0003$ & $0.0288 \pm 0.0002$ & $78.02 \pm 0.1316$ \\
\hline $\mathrm{E}_{9}$ & $10.14 \pm 1.43$ & $15.043 \pm 0.461$ & $0.67 \pm 0.11$ & $25.18 \pm 1.01$ & $0.1227 \pm 0.0052$ & $0.0271 \pm 0.0003$ & $77.836 \pm 0.8323$ \\
\hline $\mathrm{E}_{13.5}$ & $7.94 \pm 1.329$ & $13.42 \pm 1.145$ & $0.58 \pm 0.06$ & $21.37 \pm 2.35$ & $0.1014 \pm 0.0046$ & $0.0225 \pm 0.0007$ & $77.802 \pm 0.3799$ \\
\hline $\mathrm{E}_{18}$ & $7.75 \pm 2.5$ & $13.27 \pm 0.204$ & $0.58 \pm 0.187$ & $21.03 \pm 2.569$ & $0.0911 \pm 0.0004$ & $0.0206 \pm 0.0001$ & $77.322 \pm 0.1374$ \\
\hline
\end{tabular}

${ }^{1}$ Mean \pm S.D of three replicates, ${ }^{2} \mathrm{E}_{0}$ : tap water, $\mathrm{E}_{4.5}, \mathrm{E}_{9}, \mathrm{E}_{13.5}, \mathrm{E}_{18}: 4.5,9,13.5$ and $18 \%$ of tannery effluent, respectively.

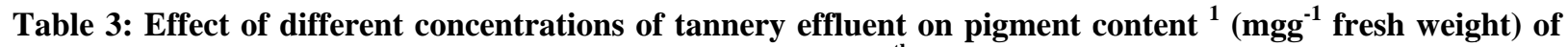
Triticum aestivum L.var. PBW-373 seedlings on $10^{\text {th }}$ day of germination

\begin{tabular}{cccccc}
\hline Treatments & $\begin{array}{c}\text { Chlorophyll } \\
\text { a }\end{array}$ & $\begin{array}{c}\text { Chlorophyll } \\
\text { b }\end{array}$ & $\begin{array}{c}\text { Chlorophyll } \\
\text { a/b ratio }\end{array}$ & $\begin{array}{c}\text { Total } \\
\text { chlorophyll }\end{array}$ & Carotenoid \\
\hline Control $\left(\mathrm{E}_{0}\right)^{2}$ & $0.0751 \pm 0.0001$ & $0.0506 \pm 0.0001$ & $1.4822 \pm 0.0025$ & $0.1257 \pm 0.0002$ & $0.4656 \pm 0.0001$ \\
$\mathrm{E}_{4.5}$ & $0.104 \pm 0.0002$ & $0.095 \pm 0$ & $1.0947 \pm 0.0021$ & $0.199 \pm 0.0002$ & $0.7991 \pm 0.0002$ \\
$\mathrm{E}_{9}$ & $0.1003 \pm 0.0005$ & $0.0824 \pm 0.0004$ & $1.2171 \pm 0.0043$ & $0.1827 \pm 0.0009$ & $1.1842 \pm 0.0004$ \\
$\mathrm{E}_{13.5}$ & $0.0711 \pm 0.0012$ & $0.0472 \pm 0.0006$ & $1.506 \pm 0.0455$ & $0.1184 \pm 0.0007$ & $1.1996 \pm 0.0002$ \\
$\mathrm{E}_{18}$ & $0.0627 \pm 0.0006$ & $0.041 \pm 0.0011$ & $1.526 \pm 0.0302$ & $0.1039 \pm 0.0016$ & $1.197 \pm 0.002$ \\
\hline
\end{tabular}

\footnotetext{
${ }^{1}$ Mean \pm S.D of three replicates, ${ }^{2} E_{0}$ Tap water, $E_{4.5}, E_{9}, E_{13.5}, E_{18}: 4.5,9,13.5$ and $18 \%$ of tannery effluent,
} respectively. 
reduced chlorophyll content (Rao aand Kumar, 1981; 1983). Lakshmi and Sundramoorthy (2001) while working on paddy treated by tannery effluent observed that upto $10 \%$ concentration of effluent the chlorophyll-a, chlorophyll-b and carotenoid content were higher which may be due to the reduced toxicity of effluent to an optimum level by dilution which favoured high pigmentcontent. The carotenoid showed an increase up to $E_{13.5}$ of effluent treatment and decreased slightly in $E_{18}$. It may be attributed to enhancing influence of increased nitrogen on carotenoid biosynthesis (Cottenie, 1973).

\section{Conclusion}

The present study shows that the tannery effluent has an evident toxic effect on the germination, seedling growth and pigment content of Triticum aestivum when applied at higher concentrations. The observations shows that at lower concentration (4.5 percent) the effluent has better effect than other concentrations in overall growth of the seedlings. Guruprasada and Kumar (1983) also observed that $5 \%$ concentration is beneficial for plants while studying the impact of tannery effluent on seed germinability and chlorophyll content in Cicer arietinum L. which is in conformity with the present study. Thus, tannery effluent needs very high dilution before its disposal in agricultural fields.

\section{Acknowledgements}

The authors are thankful to Head, Department of Environmental Sciences, University of Jammu, Jammu (J\&K) for giving essential facilities and tannery industry (Jalandhar) for providing the effluent samples for conducting the present study.

\section{References}

Arnon, D.I., 1949. Copper enzymes in isolated chloroplast polyphenol oxidase in Beta vulgaris.Plant physiology, 24: 1-15.
Czabator, F.J., 1662. Germination value, an index combining speed and completeness of pine seed germination.Forest science, 8: 386-396.

Duxbury, A.C. and Yentsch, C. S., 1956.Plankton pigment monograph.J. Mar.Res, 15: 92-101.

Greenberg, A.E, Connors, D. Jenkins and M.A. Franson, 1995.Standard methods for the examination of water and waste water $\left(15^{\text {th }} \mathrm{Edn}\right)$.American public health association, Washington D.C.

Rao, G and Kumar, N. V., 1981.Physico-chemical characteristics of tannery effluent contaminated irrigation reservoir. Ind. J. env.hlth, 23: 239-241.

Rao, G. and Kumar, N. V., 1983.Impact of tannery effluent on seed germinability and chlorophyll content in CicerarietinumL. Pollution research, 2: 33-36.

Karunyal, S. G. Renuga and Paliwal, K., 1994. Effects of tannery effluent on seed germination, leaf area, biomass and mineral content of some plants.Bioresourcetechnology, 47: 215-218.

Khurana, M.P. and Pritpal, S., 2012. Waste water use in crop production. Resources and environment, 2: 2163-2168.

Lakshmi, S. and Sundaramoorthy, P., 2001.Biochemical and mineral content changes of the paddy seedlings under tannery effluent treatment.Journal of environment and pollution, 8: 13-17.

Malaviya, P. and Sharma, A., 2011. Impact of distillery effluent on germination behavior of Brassica napus L. Journal of environmental biology, 32: 91- 94

Nath, K., Singh, D., Shyam, S. and Sharma, Y.K., 2009.Phytotoxic effects of chromium and tannery effluent on growth and metabolism of Phaseolusmungo Roxb.J. environmental biology,30: 227-234.

Sahai, R.and Srivastava, N., 1986. Effects of distillery waste on the seed germination, seedling growth and pigments content of CajanuscajanL .India bot. soc. 65: 208-211.

Sharma, V., Sharma, R. and Sharma, K.D., 2002. Distillery effluents effect on seed germination, early seeding growth and pigments contents of sugar beet (Beta vulgaris Linn. VarMezzanau -Poly). Journal of environmental biology, 23: 77-80.

Thangavel, P. and Balagurunathan, R., 2002. Effect of tannery effluents on germination and growth of certain crop plants. Bulletin of pure and applied science,21: 21-25.

Vijayarengan, P., 2003. Pollution effect of textile mill effluent on growth and development of groundnut seedlings.Nature environment and pollution technology, 2: 451-453. 